\title{
Climate change adaptation in the
}

planning and regeneration of England's

coastal areas: priorities, barriers and

\section{future prospects}

\author{
Young, D
}

http://hdl.handle.net/10026.1/14168

10.1080/09640568.2019.1617680.

Journal of Environmental Planning and Management

Taylor \& Francis (Routledge)

All content in PEARL is protected by copyright law. Author manuscripts are made available in accordance with publisher policies. Please cite only the published version using the details provided on the item record or document. In the absence of an open licence (e.g. Creative Commons), permissions for further reuse of content should be sought from the publisher or author. 
YOUNG, D. \& ESSEX, S. (in press) Climate change adaptation in the planning of England's coastal urban areas: priorities, barriers and future prospects, Journal of Environmental Planning and Management, doi: https://doi.org/10.1080/09640568.2019.1617680.

Accepted 7 May, 2019

\section{Climate change adaptation in the planning and regeneration of England's coastal areas: priorities, barriers and future prospects}

Daniel Young ${ }^{\mathrm{a}}$ and Stephen Essex ${ }^{\mathrm{b} *}$

a Planning Policy Officer, Portsmouth City Council; ${ }^{\mathrm{b}}$ School of Geography, Earth and Environmental Sciences, University of Plymouth

Daniel Young,

Senior Planning Policy Officer, Portsmouth City Council.

Dr Stephen Essex,

School of Geography, Earth and Environmental Sciences, University of Plymouth, Drake Circus, Plymouth, PL4 8AA, Devon, UK.

(Tel: +44 [0]1752-585980; email: stephen.essex@ plymouth.ac.uk)

Orcid : 0000-0002-7728-4043

*Corresponding author 


\title{
Climate change adaptation in the planning of England's coastal urban areas: priorities, barriers and future prospects
}

\begin{abstract}
Climate change is one of the greatest challenges facing society and the spatial planning system plays a crucial role in ensuring that important adaptations to the built environment are evaluated. Drawing upon a mixed-methods research approach, this paper explores the progress that has been made by the planning system in England in addressing the challenge of climate change adaptation in coastal urban areas. The results indicate that the adaptation produced through the planning system remains incremental rather than transformative. It is focused on experienced hazards, especially flooding, and there is a lack of attention being paid to wider impacts of climate change, such as rising average temperatures. Furthermore, it was found that the contemporary contribution of planning to climate change adaptation is seriously limited by the government's emphasis on housing and economic growth and by the development industry's emphasis on economic viability.
\end{abstract}

Keywords: Spatial planning; climate change; adaptation policies; planning policy; development management. 


\section{Climate change adaptation in the planning of England's coastal urban areas: priorities, barriers and future prospects}

\subsection{Introduction}

Climate change is undoubtedly one of the greatest challenges now facing global society (Carter et al., 2015; Twigger-Ross et al., 2015). The main strategies to address the challenge are: (1) mitigation, involving long-term adjustments to reduce greenhouse gases (such as through promoting renewable energy); and (2) adaptation, involving short-term adjustments to reduce the impact of climate change (such as by enhanced regulations imposed on new development, the modification of existing development, or changing human behaviour) (Zsamboky et al., 2011). The spatial planning system has a significant role to play in adaptation through strategic policy, to establish the scope of intervention, and through development management decisions over planning applications for new development (Blanco et al., 2009, p.159; Storbjork and Hjerpe, 2013). However, political systems and societies around the world have shown a distinct reluctance to plan ahead and to address environmental challenges where the impacts will not be fully apparent for many decades ahead. A range of factors can influence the level of local adaptation, such as the perceived vulnerability to climate change and the awareness, knowledge, priority and flexibility within governance structures (Picketts et al., 2014; Baynham and Stevens, 2014; Dhar and Khirfan, 2017). The majority of contemporary adaptation strategies are incremental, consisting of small changes to existing practices to sustain socio-ecological systems, rather than embracing more fundamental transformational change (Termeer et al., 2017).

Indeed, Storbjork and Hjerpe (2013) assert that the planning response to climate change is either lacking or insufficient because of the key difficulties that arise from promoting climate adaptation at the same time as balancing other competing agendas. Thus, during the global 
recession, there has been an overriding imperative to promote economic growth and property construction. Conflicts exist between the creation of universal goods (such as climate mitigation measures) and the needs of a range of local stakeholders who strive to meet targets for new house building and employment, or seek adequate economic returns from development projects. Reviewing these incompatibilities, Bulkeley (2006, p. 213) raised a critical question about the inadequacy of the ways in which climate change was being addressed within planning's 'multi-agenda policy environment' and, therefore, its intrinsic inability to deliver necessary climate change adaptation.

In 2006, Elizabeth Wilson provided an important insight into the implementation of adaptation strategies by local planning authorities in the United Kingdom and the underlying attitudes amongst planning professionals during the first five years of the twenty-first century. Wilson (2006) found that planners had defined their role in climate change adaptation very narrowly, confining their attention to flood risk. Wider implications, such as biodiversity and water resources, did not appear to feature on their agenda. A lack of political support, uncertainty about the precise impacts at the local scale, and the relative isolation of planning from other local authority and climate change networks were also offered as partial explanations of the inadequacy of the planners' approach. Wilson recognised that the longterm implications of climate change were not easily addressed within the short-term horizons of local plans. Elizabeth Wilson's insights were, of course, offered more than ten years ago and the cumulative experience with policy and practice since 2006 might well be expected to have advanced the debate considerably. Clearly, a new evaluation is required.

This paper [re-]assesses the formulation and implementation of climate change policy in English local planning authorities. However, the focus is on coastal urban areas, which are 
located in geographical zones that are especially vulnerable to the impacts of climate change. The objectives of the research were three-fold. First, to examine the content of adaptation strategies being promoted within coastal local planning policy, using a content analysis of current Local Development Frameworks and Local Plans that have been approved since 2012. Second, by means of semi-structured interviews with senior planning officers, to assess the internal factors within local planning departments that affect the formulation of climate change adaptation policies. Third, through a questionnaire survey of development management officers, to evaluate the effect of coastal local planning policy regarding climate change adaptation on development management decisions. The results reflect on the prospects offered by incremental and/or transformational adaptation to climate change in the English planning system.

\subsection{Climate change and planning on the coast}

In England, predictions for climate change suggest hotter and drier summers, with increased risks of heat waves and droughts, exacerbated in towns and cities by the 'urban heat island' (UHI) effect (Harlan et al., 2006; Luber and McGeehin, 2008; DEFRA et al., 2018). Higher temperatures are expected to increase heat-related mortality (Committee on Climate Change website, 2017a), with some projections predicting a 90\% increase in heat-related deaths between 2020 and 2050 (Vardoulakis et al., 2014). Winters, on the other hand, will become milder and wetter with an increased likelihood of severe storm and flood events (Zsamboky et al., 2011). At the coast, these effects will be accompanied by the particular impacts related to rising sea levels, which will exacerbate the height of storm surges together with increased erosion and inundation of low lying land (Vega-Leinert and Nicholls, 2008; Gehrels and Long, 2008). 
The adaptation to climate change through the planning system is likely to be acutely necessary in coastal communities because, at these locations, anticipated environmental changes are expected to be at their most extreme (Fletcher and Potts, 2008; Kron, 2013). In England and Wales, about 6.2 million people live in 273 coastal urban areas, representing about 11 per cent of the total population (ONS, 2014, p.4). A variety of significant economic sectors are concentrated in the coastal zone, including international trade in ports, fishing and tourism. In the coastal zone of the UK alone, 2.4 million properties are estimated to be at risk from flooding. Without intervention, 5,000 properties are in danger of being lost due to coastal erosion by the year 2030, rising to 28,000 by 2060 (Environment Agency website, 2016). As well as significant infrastructure, the coast also hosts some of the country's most important natural habitats and heritage.

Furthermore, the demographies of coastal communities tend to feature above average numbers of vulnerable social groups whose particular socio-economic characteristics exacerbate their climate risks. These areas have been reported to have higher proportions of elderly residents (Beatty et al. 2008 and 2011) as well as benefit claimants and low-income individuals (Rickey and Houghton, 2009). Harlan et al., (2006) showed that the negative impacts of climate change, such as heat stress, are felt hardest in the poorest, most marginalised communities, largely because they possess inadequate resources for coping with higher temperatures. Furthermore, deprived communities are also more susceptible to the impacts of water damage from storms and floods because of the lower resilience of their properties and insufficient money to pay for flood defence equipment. Their properties are therefore likely to be impacted more severely than those belonging to higher income groups (Walker and Burningham, 2011). Elderly folk, and those with pre-existing medical 
conditions, who dwell in coastal communities, have also been identified as being at risk during extreme climate events because their bodies may adapt less well to extreme temperatures (Luber and McGeehin, 2008; Walker and Burningham, 2011). Climate change adaptation has the potential to reinforce existing spatial inequalities between urban areas and different demographic groups, as well as create new injustices through infrastructural investment that protects wealthier communities and assets, but displaces poor and marginalised groups (Meerow and Mitchell, 2017).

\subsection{Spatial planning and adaptation}

Notwithstanding Bulkeley's (2006) scepticism, spatial planning is well placed to address the cross-sectoral challenge of climate change (Greiving and Fleischhauery, 2012) and can deliver adaptation on the coast through a variety of measures. The mitigation and adaptation of climate change represent core planning principles of the National Planning Policy Framework (NPPF) (DCLG, 2019, p.5). Paragraph 149 of the framework sets out that the plans of local planning authorities:

“...should take a proactive approach to mitigating and adapting to climate change, taking into account the long-term implications for flood risk, coastal change, water supply, biodiversity and landscapes, and the risk of overheating from rising temperatures. Policies should support appropriate measures to ensure the future resilience of communities and infrastructure to climate change impacts, such as providing space for physical protection measures, or making provision for the possible future relocation of vulnerable development and infrastructure" (p. 44).

Guided by what has been prescribed in the NPPF (DCLG, 2019), local authorities (LAs) have an important role in helping to build resilience to climate change through their 
Local Plans, which should demonstrate a "holistic understanding" of the variety of adaptation responses (TCPA, 2012, p. 8). As the Town and Country Planning Association (TCPA, 2012) highlights, local plans have the potential to contribute a variety of effective solutions to the issues arising from climate change, and should treat climate change "as central to policy formulation" (p. 10). Policy makers are advised to interrogate the available evidence about climate hazards and the various socio-economic factors of their local areas in order to reduce the risks of disastrous climate related consequences occurring in the future (Kron, 2013). Dupuis and Biesbroek (2013) proposed four main groups of adaptation policies (Figure 1). The least effective group were 'contiguous' policies, which had been originally formulated to meet other objectives rather than relating directly to climate change. These policies could facilitate adaptation, but do not instigate it outright. In contrast, 'concrete' policies are most effective, being those that have been formulated specifically to manage the impacts from anticipated long-term climate change.

[Figure 1 near here]

Kron (2013) suggests that policies can work to restrict new development from occurring in identified high-risk areas along the coast. Furthermore, if climate risks, such as the impacts of extreme heat events or flooding, fall disproportionately on the vulnerable groups in society, then Local Plans can work to identify the most endangered areas, and formulate policies that specifically aim to reduce the hazard in these areas (Harlan et al., 2006). Ultimately, however, not all coastal areas can be made resilient to climate change, and Local Plan policies then have a role in enabling managed retreat through facilitating changes in land-use and relocating development to places of lower risk (Environment Agency, 2015). Local Plans can also emphasise how adaptation strategies can achieve wider policy objectives 
(Wilson, 2006). Green infrastructure policies, for example, have become a common adaptation strategy because they offer benefits that extend beyond the reduction of carbon dioxide emissions to the management of the urban heat-island effect, the mitigation of flood risk and the development of ecosystem resilience (Sussams et al., 2015; Allman, et al., 2004).

The UK planning system is a discretionary one (Claydon and Smith, 1997; Hart, 2015). Once a Local Plan is adopted, planners in development management must interpret its policies and balance them with other material considerations when making decisions on planning applications. About $90 \%$ of planning applications received by authorities are decided by planning officers under delegated powers (DCLG website, 2015). Thus, planning officers in development management have an important role to play in safeguarding adaptation to climate change through their decisions regarding planning applications. Development is usually permitted subject to conditions (Hart, 2015), which can be an effective way of ensuring that new development reduces the impacts of climate change, such as through green infrastructure to mitigate high temperatures, or sustainable drainage schemes to moderate surface run-off (TCPA, 2012). Planning obligations can also address climate change; for example, an agreement might require developers to pay for new infrastructure, such as flood defences (Hart, 2015).

A number of challenges face the implementation of effective adaptation action through planning intervention, which prompted Storbjork and Hjerpe (2013) to assert that planning responses to climate change often remain highly rhetorical or symbolic. First, restrictions over development in locations most vulnerable to climate change, such as waterfronts, are difficult to enforce because the perceived benefits (for example, enhanced quality of life) can outweigh any imagined risks from climate change for many stakeholders 
(Kron, 2013). The desire to drive economic development - irrespective of the risks from climate change - can be difficult to resist, particularly because of the long timescales, costs and unknowns involved in adaptation measures (Carter et al., 2015). The historical propensity to allow large amounts of building upon flood plains is the clearest possible evidence of this effect (Deeming et al., 2011). Indeed, Storbjork and Hjerpe (2013) found that development of waterfront locations in Sweden was often driven by economic and political pressures for housing in attractive locations, which eclipsed concerns about their vulnerability to climate change hazards, and ultimately undermined the creation of resilient and sustainable communities. This factor highlights that there can be political difficulties in prioritising climate change adaptation over other competing objectives (Picketts et al. 2014).

Second, some of these issues are also relevant to the deliverability of planning conditions and obligations, which planners can require of developers to secure appropriate climate change adaptation through the development management system. However, imposing such measures can increase the costs of a project to the developer and threaten its viability (Townshend, 2015). There continues to be a challenge of balancing the requirements placed on developers for adaptation measures, alongside other commitments, such as for affordable housing, versus the viability of a proposed project.

A third challenge arises because policy formulation tends to be based on experienced risks, usually involving physically destructive events that leave a tangible impact (i.e. 'disaster-driven'). Water-related impacts, especially in relation to flood hazards, which are already common events, have been the main and most advanced of adaptation planning policies (Greiving and Fleischhauery, 2012). Other hazards, such as hotter summer temperatures and the ensuing heat waves, which can be described as 'silent killers', tend not 
only to be experienced infrequently in the UK, but also leave little behind in terms of environmental destruction. They are therefore less influential on the public and policy formulation in the long-term and are easily forgotten once the hot weather has passed (Luber and McGeehin 2008, p. 429). Other impacts, such as those from drought and storms, as well as on biodiversity, have also largely been neglected in policy formulation (Wilson, 2006).

Fourth, LA budgets have been subject to extensive cuts due to austerity measures following the 2008 recession (Porter, et al., 2015; Romsdahl, et al., 2017). A study by the TCPA (2016) assessed 64 authorities across England for their responses to climate change and concluded that, because of resource constraints, climate change was no longer a priority in local planning. LAs were "not planning for the adaptation measures necessary to secure long-term social and economic resilience" (TCPA, 2016, p. 3). Resource cuts also have implications for the skills capacities of many planning departments and the levels of in-house knowledge relating to climate change, which ultimately affects their ability to deliver suitable adaptation. These issues can be compounded by a lack of institutional ownership and leadership of problems as well as fragmented institutional collaborative arrangements (Uyl and Russel, 2018).

There are other challenges too. For example, research by Sussams et al. (2015) suggested that there is considerable confusion and lack of understanding on the part of many policy makers regarding the benefits of climate change actions. Green infrastructure, for example, is a 'fuzzy concept'. Due to poor understanding, policies supporting the adoption of green infrastructure are therefore not achieving all of their potential multi-functional benefits. The result is that development management officers are uncertain about how to apply a policy in assessing a planning application. Furthermore, Jennings (2011) has argued that, as a 
"product of neoliberal thinking", responsibility for climate change adaptation has partly shifted from central government to property owners, who have been encouraged to reduce their own risks as much as possible through insurance cover (Deeming et al., 2011). This partial abdication of responsibility by the state can have implications for the poorest members of society, who cannot afford such insurance in the first place, which further compounds their vulnerabilities (Deeming et al., 2011).

\subsection{Methodology}

In order to investigate the formulation and implementation of climate change policies by planning departments within coastal local authorities (LAs), a clear sampling population and strategy was devised. The Marine Management Organisation's (MMO) definition of 'coastal' areas was adopted for this study, involving all Lower Super Output Areas (LSOAs) extending "10 km inland from the low water mark", but excluding the boroughs of Greater London and any LSOAs with less than $15 \%$ of their area within the $10 \mathrm{~km}$ buffer zone (MMO, 2011, p.7). Within this sampling population, it was decided to focus on any LA with an approved or draft Local Plan/Local Development Framework in the five years before September, 2017 (ie. 2012-17). The government advises that, whilst Local Plans will age at differing rates, most "are likely to require updating in whole, or in part at least every five years" (DCLG, NPPG website, 2017). There were 67 coastal LAs in this category, which therefore formed the sample base for this research. A mixed methods approach was utilised to evaluate the formulation and implementation of climate change adaptation policies by local authority planning departments. The research was undertaken between May and September, 2017.

\subsection{Desk-based analysis of Local Plans}


The content of adaptation strategies within the planning policy was examined using a deskbased analysis of the Local Plans adopted in the previous five years (2012-17). For this part of the methodology, it was decided that only those plans that had been approved and adopted would be analysed from the total sample of 67 LAs. This decision was taken because there was still scope for those published in draft form to be amended prior to full adoption. With several of the authorities working together on a joint plan rather than undertaking individual plans, a total of 39 plans were investigated in detail for this part of the study (Figure 2). An analytical framework was devised to analyse the content of each plan, which was organised into several sections (Table 1). The first section aimed to evaluate broad awareness and understanding of climate change, as demonstrated by the plan. The plans were also assessed more specifically for acknowledgement of major climate change impacts that required adaptation measures, including temperature rises, sea-level rise, precipitation changes and extreme storm events (Blanco et al., 2009).

[Figure 2 near here]

[Table 1 near here]

Sections two to four of the analytical framework were adapted from the UK Climate Change Risk Assessment report (Committee on Climate Change, 2017b). The individual categories that came under each section assessed specific areas of risk that are projected to be faced in the UK as a result of climate change in the future according to the report (column two of Table 1). Every plan was then evaluated to gauge whether they addressed these risks and to what degree. The final section of the framework examined evidence of specific 'adaptation strategies', such as green infrastructure, sustainable urban drainage systems 
(SUDS) or climate-resilient urban design. Drawing on the approaches adopted by Baker et al., (2012) and the TCPA (2016), a critical qualitative evaluation was made of each plan for each section of the analytical framework defined in Table 1. Based on these evaluations, quantitative scores were then assigned to the plan, section by section (Table 2).

[Table 2 near here]

\subsection{Interviews with senior policy planners and questionnaire survey of development management planners}

In order better to understand the factors behind policy formulation itself, as well as how these policies might affect decision making, additional research approaches were employed: namely, semi-structured interviews with Head/Senior Policy Planners and a questionnaire survey targeting planning officers in development management. For ethical reasons, Head Planners of the 67 LAs with approved or draft Local Plans/Local Development Frameworks (2012-17) were contacted to request the participation of both policy planners with responsibility for the formulation of climate change adaptation policies and development management planners with responsibility for making decisions on development applications. A total of 21 Head Planners granted permission for their staff to participate in the research (if they wished). As far as possible, semi-structured telephone interviews were held with a senior policy planner from each LA, who had been responsible for formulation of policies relating to climate change. Concurrently, an online survey was sent out to development management officers and a response sought from at least one officer from each authority. These interviews and surveys focused on the awareness among planners of climate change and adaptation strategies, the drivers and barriers to policy formulation, the process of writing climate change policies, and the use of these policies in development management decisions. 
Ultimately, interviews were held with 17 Senior Policy Planners regarding planning policy, which represented $25 \%$ of the study sample (four interviews could not be arranged). Online surveys were received from 35 development management planners representing 15 LA development management teams (from the 21 LAs given permission to participate in the survey). Single responses were received from nine LAs, two responses from two LAs, three from two LAs, four responses from two LAs and eight respondents chose not to identify their LA. Variability of responses from within a single LA was not considered to be an issue as the focus of analysis was on the perceptions and attitudes of planners in development management. Responses to initial requests to participate in the research indicated that a number of LAs were dissuaded from doing so due to a lack of time or staff. It is acknowledged that, as a result, the responses received may be skewed towards those LAs which have available resources.

In summary, the total sample population of coastal LAs was 67 - from which 39 had fully adopted Local Plans, which were analysed as part of the desk-top study. A total of 17 out of the 21 Senior Policy Planners who had been granted permission by their line manager to participate in the research were interviewed. A total of 35 development management planners from at least 15 LA development management teams completed the on-line questionnaire. These three sources generated complementary data, although the potential for triangulation was limited to only nine LAs, with a further eight LAs having two data sources to compare.

\subsection{Results and analysis}




\subsection{Adaptation in Local Plans}

Of the 39 local plans analysed, all acknowledged climate change to some degree, but the level of detail varied considerably. A total of $15 \%$ of the plans made acknowledgement of climate change within the wording of the plan document, but failed to explicitly address it within the wording of any planning policies. Flood events arising from sea-level rise (tidal flooding) and more intense rainfall events (fluvial or surface water flooding) were recognised most frequently, being mentioned in more than $90 \%$ of those documents. This high level of awareness of flooding as a climate change-related issue might be partly explained by previous experience of flood events and its established profile in planning policy and decision-making. The Environment Agency's flood risk maps have disciplined planners into incorporating this risk into decision-making over development applications as normal practice (Porter and Demeritt, 2012). Of less prevalence, recognised in just under two-thirds (64\%) of plans, were impacts of increased storm impacts and higher average temperatures. Strikingly, for a study of coastal LAs, almost a quarter (eight) of LAs that had a physical coastline (three of the LAs were within the defined coastal area, but not physically on the coastline), omitted to recognise explicitly that sea-level rise is a potential impact of climate change that needs to be addressed in the plan. Of the LAs with a shoreline, less than half (15 out of 36) anticipated risks to local businesses and/or infrastructure due to increased coastal erosion and the loss of coastal locations.

The broad need for adaptation to climate change (as opposed to mitigation) was addressed in the wording of a specific policy in 20 of the Local Plans (51\%). The remaining LAs made at least some reference to the need for adaptation in the wider texts of their documents if not through a specific policy. Two of the LAs, however, were exceptionally limited in discussing the need for adaptation to climate change and only made a single 
passing reference to the matter in their entire documents. The TCPA (2016) reported that $54 \%$ of plans in their national study addressed adaptation through the wording of a policy, which is broadly comparable with the findings of this study. Regardless, therefore, of the increased vulnerability to climate change from the additional impacts of sea-level rise that coastal areas face, LAs in these areas appear not to be addressing adaptation with any greater degree of priority than elsewhere in the country.

Less than one-fifth of the LAs (six) specifically acknowledged that increasing average temperatures could lead to risks for human health in the future, such as heat stress, but no LA translated this concern into a specific Local Plan policy (Table 3). Again, matters of water management appeared to have more attention as over two-thirds acknowledged that there could be risks to water supplies as summers become drier across the country (27). More than half of these LAs had formulated a specific policy that addressed the problem of water shortages related to climate change (15).

[Table 3 near here]

The lower attention afforded to risks arising from increased storm impacts and higher average temperatures within climate change adaptation plans and policies might indicate a lack of awareness and understanding of climate change science by planners. Porter, et al. (2015) have argued that there is a 'climate information usability gap', whereby planners need different kinds of information, such as costs and monetary implications of climate impacts, in order to translate the climate science into adaptation plans and tangible actions. In addition, planners require information that can secure political support and demonstrate that policy is proportionate to its expected costs and benefits (Kuklicke and Demeritt, 2016). 
Most commonly, there were examples of what Dupuis and Biesbroek's (2013) would describe as 'contiguous' or 'contributive' policies, which were formulated to achieve sustainability or biodiversity goals as opposed to concrete policies that explicitly and directly addressed climate change adaptation. These contiguous or contributive policies included measures such as green planting to increase shading and reduce urban heat island effects, or water efficiency measures in new buildings to reduce water demand. The majority of the plans also featured policies that relate to sustainable urban drainage schemes (SUDS) (33) and climate resilient urban design (24). Green infrastructure was by far the most prevalent policy and featured in all the Local Plans. These findings substantiate research by Romsdahl, et al. (2017), which suggested that many local government practitioners have adopted alternative or substitute frames or agendas, such as sustainability, energy and fuel poverty, in order to secure political support and so make progress with climate adaptation planning.

These findings indicate that issues of water management are still the strongest priority for most LAs when it comes to climate change, which matches the position recognised in previous research (e.g. Wilson, 2006; Greiving and Fleischhauery, 2012). Apparently, during the last decade, little has changed to broaden the focus of Local Plan policies towards other, non-water related, impacts of climate change.

\subsection{Formulation of adaptation planning policies}

Insights into the process behind the formulation of planning policies related to climate change adaptation were obtained from telephone interviews with the senior policy planners. According to these interviews, the initiation of such policies was driven largely by central government guidance, namely, the NPPF and NPPG (National Planning Policy Guidance), 
previous Planning Policy Statements (PPS) and related planning legislation. The response suggests that a strong top-down influence drives climate change policy formulation in plan making. Relevant Local Plan policy themes also tended to reflect local experiences of climate change hazards, in particular, extreme flooding events. A couple of the comments made by the planners noted:

“Our focus is on how we experience weather here to a large extent. We've been subject to, in the past five years, two fairly catastrophic flooding events in our main town. Flooding and weather pattern changes and their impacts on the built environment [are] very much in the forefront here." (Respondent P6).

"Locally, flood risk is such a key issue because it impacts on such a large part of our district and it impacts upon our built areas in particular.... [Addressing it] is fundamental to enabling future growth." (Respondent P9).

In part, this focus on experienced flood hazards was because these issues were at the forefront of the minds of the planners writing these policies, as well as elected members and the local public. It was indicated that these were not only issues that had been experienced recently, but they were also hazards that were perceived to have increased most noticeably over the last few years and presented the most significant threat to impeding development and growth. Also, however, flooding and coastal change was something for which the planners had the most well developed and extensive evidence base. As such, writing strong evidence based policies was considered to be much easier than for some other climate change hazards, such as the threats from increased summer temperatures and heat waves. 
At least four respondents, however, acknowledged that the emphasis of central government leadership on climate change adaptation was changing or had changed.

Contemporary central government priorities were perceived to be related to economic growth and delivery of new development (such as the current Conservative government's pledge to raise housing supply to 300,000 per year, on average, by the mid-2020s). This emphasis had somewhat subordinated climate change action in local planning. A number of planners raised this issue:

"There is this absolute national drive to deliver housing at, not at all costs, but clearly the environmental agenda, the climate change agenda, you do not hear them mentioned in the planning debate at all now. If anything, if you raise it (environment/climate change agenda), it is seen as an obstacle to housing delivery. I think it's a real issue because you're then pushing this large-scale development, which isn't future-proofed and personally I find that quite concerning." (Respondent P6).

"Since the Coalition government came in (and onwards), the national mood music has not been about climate change and mitigating climate impacts. It's been about economic growth and house building. Before, I would say with the previous Labour administration, there was more banging the drum about it, there were more measures put in place, you were aware of a balance being struck and that has gone." (Respondent P16). 
"They're not going to win or lose elections on climate change policy, whereas you know, housing policy or something else, might have more of an impact...." (Respondent P17).

At least four of the respondents believed that this national political rhetoric filters down to local level leadership and subsequently also influences local elected members' priorities. Thus, local government imperatives, as with central government, are shaped primarily by the economic development agenda and adaptation to climate change has been relegated to a lower priority position:

"If you haven't got the national picture saying this should be up in your top ten, top three, top four issues to resolve in your plan, the politicians (local) aren't going to go for it and they won't spend the resources on it." (Respondent P16).

Whilst respondents generally remarked that their elected members seemed reasonably aware of the need to respond to climate change, three respondents believed that the issue was not a big enough political priority to motivate the elected members to 'drive' policy formulation in that area themselves. Two respondents highlighted that the policies have been formulated because of the persistence of a few individuals within the planning department itself, rather than politicians. One noted:

"The drivers would have been advised by the team... I don't see, with the current (local government) administration, that there is a huge political driver about climate change. There is a knowledge of, and an awareness of... it is not something they 
would say is in the centre of their (elected members') agenda to do something about." (Respondent P16).

These influences might help to explain why the reviewed policy documents had adopted substitute agendas in order to progress local climate adaptation planning (Romsdahl, et al., 2017).

Nevertheless, the effect of public spending cuts on the limited resources of LAs was also recognised. There was a general consensus that things felt like they had gone backwards, with officers recognising a reduced profile for climate change within the LAs, including the loss of in-house knowledge and skills:

"One of the main barriers for us was the lack of in-house skills to do some of this work, and that's probably more so now than before... There are less skills and resources now than there were when we produced the last plan... going forwards that's going to be an issue for us in moving this new plan forwards." (Respondent P5).

"For example, four/five years ago, maybe slightly more, we had government money to employ a climate change officer; we had one in house. We had a climate change action plan as a council, and all that's gone. You don't even hear about it... I think we will look back with some concerns." (Respondent P6).

One individual felt that austerity measures and ensuing restructuring within the department had led to the erosion of knowledge relating to climate change in their team with 
impacts upon Local Plan development. Another respondent held the same view, stating that there was no longer the budget to fund more specific climate change expertise in house as it "was not a government priority" (Respondent P6). A further important factor in the failure of LAs to deliver climate change adaptation as 'public goods' through new development was the propensity of developers to challenge such conditions on the basis of economic viability. A number of development viability issues, such as the additional costs of remediating contaminated land or other legacies from previous development, modest land values, and new infrastructure demands, hampered the ability of LAs to place additional demands on developers through the plan or development management decisions. One planner noted:

"The introduction of viability testing in planning is a real issue. You've got the County Council asking for highway improvements, education contributions, affordable housing contributions, and climate change adaptations are well down the list, if they are talked of at all." (Respondent P6).

“On balance... we've also got a very, very strong message from central government downwards about delivering, and if push comes to shove, if we were negotiating, it's about getting consents out, getting things built. And I think, I'd have to say some of the adaptation ambitions that come in the 'nice to have', they are more achievable in certain areas than others." (Respondent P9).

Viability also often resulted in a watering down of the direction of policies in the plan, which weakened the power of the authority to drive such adaptations in new developments: 
"The wording tends to be greatly watered down, with words such as 'encourage' instead of 'must', or 'subject to viability' ... From a negotiation point of view, it (adaptation) ends up as a 'nice to have' and, of course, developers and their consultants are pretty apt at demonstrating why they'd love to do it, but unfortunately their scheme doesn't allow it." (Respondent P15).

Viability was expressed as a source of frustration by one planner, who remarked that many adaptations included in new buildings, such as plug sockets being placed above the level of possible flood-water incursion, could save a lot of money in the long term. They pointed out that such adaptations were a relatively cheap addition if factored into the initial design and development process, but were much more expensive if retro-fitted years later. Another respondent proposed that one reason for the lack of desire of developers to incorporate adaptation measures into new housing was that, whilst it was recognised that many measures could save buyers' money in the long term (such as energy efficiency bringing energy savings) and therefore make a better product for the buyer, the demand for new housing at present meant that people were essentially willing to buy whatever new homes are available, regardless of the level of climate change adaptation. At present, therefore, there was in fact very little market incentive for developers to meet additional adaptation costs for climate change in their new developments.

National house-building companies were recognised by at least three authorities to be a source of many objections at consultation phases on viability grounds. Such companies argued that adaptation measures put forward by the LAs would simply be unviable: 
"It's a difficulty of working with mainly national house builders... Because of their standardised house types, it's a lot harder to negotiate changes and adaptation rather than with smaller regional or local house builders. They will build to the minimum: to what building regulations say they have to do. It is quite hard to go further than that." (Respondent P9).

One respondent suggested that viability testing had become an important driver in their development management process. Another planner noted that the inclusion of climate change adaptation in planning policy formulation was beginning from an economic standpoint of what would be affordable and viable to deliver a sound plan rather than from a viewpoint which emphasised what was truly needed to ensure resilience for communities (or the 'public good') (Respondent P9).

\subsection{Development management decisions}

Development management officers reported that the level of awareness about climate change demonstrated by planning permission applicants was limited $(62 \%)$ or rare $(28 \%)$. Only two respondents who completed the survey felt that applicants had demonstrated a good awareness:

“...it very much depends on the applicant and the quality of their agent. Some take the issue much more seriously than others. There is a lack of understanding amongst some applicants/agents and I find [climate change] is not a matter that weighs heavily in their thinking..." (Respondent DM14). 
"Applicants of proposals for large-scale development will have a very good level of awareness of the implications. This is because the applicant is usually supported by a team of specialists. Applicants for smaller-scale development will tend to have less awareness but are taken through the process by the planners at pre-application stage." (Respondent DM26).

In keeping with the findings from the interviews with policy planners, another perceived barrier which seemed to moderate developers' commitment to climate change adaptation was that of the economic concerns outweighing other priorities, with adaptation simply not being perceived as commercially justifiable:

"It will cost developers more money so they try to avoid it." (Respondent DM20).

“... Typically, economic issues take centre stage.” (Respondent DM32).

Crucially, these observations indicate that, even before the planning process has an opportunity to assess the implications of development proposals, developers lacked a commitment to climate change issues and/or were swayed by financial viability priorities. As two planners noted:

"Getting the development industry to take it seriously. All too often the attitude is that their little development will not create an impact. The challenge is to change the culture and to get everybody to acknowledge the cumulative impact or bigger picture." (Respondent DM2). 
"Large scale developments are strongly led by developers and profit." (Respondent DM24).

Arguably, this challenge places a bigger burden on the planning officers to make up the shortfall in adaptation action in two ways. First, through awareness-raising about the need for adaptations in pre-application meetings and, second, through resilience-building through the use of planning conditions to ensure that development proposals are adequately futureproofed against climate change. Additional comments suggested that climate change was often seen as an implicit expectation of developers by the planning department and not something that requires a specific conversation in pre-application discussions:

"The discussions are not explicitly on climate change, but climate change is implicit in the requirements which developers are expected to achieve, for example in relation to drainage... a separate conversation on climate change is rare (unless part of a scheme relevant to climate change, such as renewable energy)." (Respondent DM6).

Indeed, this implicit expectation that developers know about climate change requirements could be considered flawed given the earlier finding that many officers felt that applicants generally do not possess this knowledge. An interpretation of these results is that the development management process, at least at the pre-application stage, is not playing a sufficiently robust role in ensuring resilience-building of built environments to the impacts of climate change. Nevertheless, later on in the development management process, $70 \%$ of respondents stated that they had used planning conditions or obligations to build in resilience to climate change into proposals. The conditions/obligations tended to be principally related to water management, such as flooding and drainage, including a range of measures such as 
flood alerts, flood evacuation plans, flood-risk assessments, and elevated ground-floor levels. Little reference was made to building resilience to other impacts such as higher temperatures. These findings might suggest that planners require more useable information from the science of climate change to facilitate the formulation of practical and politically defensible plans, policies and actions (Porter, et al., 2015).

\subsection{Discussion}

This paper has sought to understand how coastal urban areas are responding to climate change and to evaluate the response of English LAs on the coast to the challenge, specifically in terms of adaptation. While many Local Plans demonstrated a good level of awareness about the impacts of climate change for their local areas, few went further than acknowledging that climate change was occurring. The plans often failed to frame how the particular impacts of climate change might present challenges for the development of their local areas in the future.

The towns and cities of coastal LAs are particularly vulnerable to climate change risks both in terms of their geographical exposure to impacts such as sea-level rise, but also due to their above average concentrations of vulnerable populations. Yet numerous authorities have simply not yet recognised the full spectrum of changes that are projected to impact upon them. Indeed, a number even neglect to highlight the projected risks presented by the defining feature intrinsic to coastal spaces: that of the sea and, more specifically, rising sea levels.

It is evident that the focus of adaptation action and risk prioritisation by local authority planners is largely prescribed by national guidance and the management of 
experiential risks, such as flooding and inadequate drainage. The majority of plans included measures related to the risk management of new development, such as SUDS and flood defences. The overriding attention paid to flood risk over all other climate impacts was not just a feature of planning policy, but also in the outcomes of the development management process. Planners have been disciplined into considering flood risk through the availability of flood risk maps supplied by the Environment Agency. Locally specific information on other climate change risks do not presently exist in such useable forms.

A striking finding that emerged from this research was that very little has changed during the past decade to broaden local authorities' policy focus towards the wider range of climate change impacts that are, or will, affect their areas. Several drivers and barriers seem to be moderating the response of coastal local authority planning departments to climate change. Central government guidance was highlighted as having exerted a powerful influence on climate change policy in Local Plans yet, since 2010, its priority has switched decisively in favour of economic growth, leaving LAs to work without strong environmental leadership. However, the value of forceful guidance from central government is clearly conveyed by the comments from one officer who referred to the power of the 'national mood music'. Having clear direction from the top not only ensures that those formulating policy at the local level know what to prioritise in their own strategic objectives, but also gives the confidence of support from the highest level when preparing a plan for examination. Furthermore, clear guidance from central government can engender a greater level of support from elected members locally, prompting greater allocation of spending on adaptation measures.

The perception expressed by respondents that the environment and climate change agenda "is seen as an obstacle to housing delivery" was also concerning. It raises a question 
over whether the apparent focus of government policy on delivering new housing and economic growth is serving to undermine the delivery of sustainable development, such as climate adaptation. The future risks that climate change poses to the built environment and its inhabitants are now well documented in the literature, which emphasises the consequences should adequate adaptation not take place. Yet if addressing climate change is perceived as an obstacle to development rather than a goal, the ability of planners to achieve sustainability is clearly impaired. Thus, the recommendation of the TCPA (2016) that there needs to be a renewed focus and strengthening of direction provided by central government on how LAs should work to adapt to climate change is powerfully supported by the findings of this research.

Another key finding of the TCPA (2016, p. 3) report was that "specific approaches to dealing with climate change are still novel to many local authority planners, and access to affordable training is a major issue". The results from this research seem to indicate that training is a necessity in coastal LAs to build capacity to tackle climate change through planning. Indeed, the comments by several respondents relating to awareness of adaptation strategies suggest that the only knowledge that planners possess with regard to effective adaptation is self-taught. The lack of formal training casts doubt on whether planners are genuinely abreast of the adaptation agenda, or adequately aware of the growing suite of measures that planning might utilise to adapt the built environment to climate change.

The interview responses reveal the importance of the planning department in driving the formulation of climate change adaptation policy. Planning officers are primarily responsible for the adaptation policies featured in the Local Plans, rather than other stakeholders, such as elected members. Indeed, relying on the development industry to drive 
adaptation does not currently appear to be feasible. Development management planners report that there is very little awareness or willingness among applicants to embed adaptations to climate change within their proposals. Many stakeholders simply seem to be driven by other priorities, such as economic development. Arguably, therefore, there is an even greater burden upon planners to ensure that adaptation to climate change is at least considered in new development. This increased responsibility only increases the value of good training and realistic resourcing levels to ensure that they can promote adaptation through planning where these other stakeholders have conflicting priorities.

Finally, the topic of economic viability was one that was cited frequently as a major challenge for climate change adaptation. There is a sense that planning policies relating to adaptation are currently limited in their innovation and scope to only the minimum required by national policy, and that the authorities often face difficulties when trying to go any further due to objections on the grounds of viability. As a couple of respondents highlighted, viability seems to be a particular issue for coastal areas when it comes to attracting new development, related to issues of moderate land prices, major infrastructure investment needs, and obstacles presented by previously developed land or contamination. The result is that adaptation strategies are having to compete with other demands and, as a result, are often relegated as merely 'nice to have' options. The impact of such concerns about viability is that the climate change response of coastal LAs is being constrained, with serious potential implications for the resilience of built environments to conditions that will be encountered in the future. The implication is that the perception of adaptation measures needs to change, so that they become more valuable to the development in terms of viability. Until a longer term view of development is realised widely, adaptation to climate change through the planning process does not appear likely to be achievable to the fullest extent. 


\subsection{Conclusions}

This research investigated the response of coastal local authority planning departments to climate change, with a specific focus upon adaptation. The findings highlight that, at present, the response is alarmingly varied, with Local Plans demonstrating a great range both in the level of awareness of impacts that place their areas at very serious risk, and in the sophistication of the adaptation strategies that are being promoted through planning policy. In line with findings reported in other studies for LAs spread across the whole country, there is still a pronounced and narrow bias towards the mitigation of flood risk. Other potentially damaging impacts, such as rising summer temperatures, are still being granted little or no attention. The lack of a comprehensive, coherent and high priority emphasis on climate change adaptation in coastal areas is surely a very grave concern. Such localities contain higher than average proportions of the most vulnerable populations upon whom adverse climate change impacts have been found to fall most heavily. Adaptation to climate change through the planning system remains firmly incremental. While political imperatives change and fluctuations occur in the leadership afforded by central government, the resources available in local planning departments remain constrained. Clearly, the UK planning system has not yet developed a convincingly adequate response to climate change: one of the greatest challenges that society faces today.

The findings of this paper offer some new insights and directions in climate change adaptation research and policy. First, it is clear that planners require useable information from climate science which provides location-specific estimates of a wider range of climate change impacts, even if these are couched in uncertainty. Such information would provide an evidence base for local policy formulation and as a basis for decision-making on 
development proposals, which can be more easily justified and defended politically. This need for an accessible evidence base that relates to the real world effects of climate change represents a challenge to the scientific community. Second, more policy focus and research effort might be given to assessing the awareness, knowledge and responsibility of other stakeholders, especially developers, about climate change. This paper has indicated that developers often use viability considerations (perhaps cynically) to reduce or negate their planning obligations towards climate change adaptation, despite these offering cost effective innovations and potential long-term value for their investments in new development. Third, a higher profile might be given to policy and research into the potential social inequalities and injustices that climate change adaptations presents to coastal communities, especially the poor and elderly. Existing disadvantages might be accentuated and new inequalities created by decisions about which areas are protected or not by adaptation infrastructure. 


\section{Acknowledgments}

The authors would like to thank Professors Mark Brayshay and Gerd Masselink for their constructive comments on a previous draft of this paper. Credit also to Jamie Quinn and Tim Absalom for the cartography.

\section{Declaration of interest statement}

No potential conflict of interest was reported by the authors. Daniel Young is currently a Planning Policy Officer with Portsmouth City Council, but undertook this research separately at the University of Plymouth, 2016-17 before taking on his current role in Portsmouth.

\section{References}

Allman, L., Fleming, P. and Wallace, A. 2004. "The progress of English and Welsh local authorities in addressing climate change." Local Environment 9 (3): 271-283. doi: https://doi.org/10.1080/1354983042000219379

Baker, I. Peterson, A. Brown, G. and McAlpine, C. 2012. "Local government response to the impacts of climate change: An evaluation of local climate adaptation plans." Landscape and Urban Planning 107: 127-136. doi: https://doi.org/10.1016/j.landurbplan.2012.05.009

Baynham, M. and Stevens, M. 2014. "Are we planning effectively for climate change? An evaluation of official community plans in British Columbia", Journal of Environmental Planning and Management, 57 (4): 557-587. doi: https://doi.org/10.1080/09640568.2012.756805

Blanco, H. Alberti, M. Forsyth, A. Krizek, K. J. Rodriguez, D. A. Talen, E. and Ellis, C. 2009. "Hot, congested, crowded and diverse: Emerging research agendas in planning." Progress in Planning 71: 153-205. doi: https://doi.org/10.1016/j.progress.2009.03.001

Beatty, C. Fothergill, S. \& Wilson, I. 2008. England's Seaside Towns: A 'benchmarking' study. London: DCLG.

Beatty, C. Fothergill, S. \& Wilson, I. 2011. England's Smaller Seaside Towns: A benchmarking study. London: DCLG.

Bulkeley, H. 2006. "A changing climate for spatial planning." Planning Theory and Practice. 7 (2): 203-214. doi: https://doi.org/10.1080/14649350600681875

Carter, J. G. Cavan, G. Connelly, A. Guy, S. Handley, J. and Kazmierczak, A. 2015. "Climate change and the city: Building capacity for urban adaptation." Progress in Planning 95: 1-66. doi: https://doi.org/10.1016/j.progress.2013.08.001

Committee on Climate Change. 2017a. "Tackling climate change." Committee on Climate Change. Accessed July 10 2017. https://www.theccc.org.uk/tackling-climate-change/ 
Committee on Climate Change. 2017b. "UK Climate Change Risk Assessment synthesis report." Committee on Climate Change. Accessed July 152017. https://www.theccc.org.uk/wp-content/uploads/2016/07/UK-CCRA2017-SynthesisReport-Committee-on-Climate-Change.pdf

Claydon, J. and Smith, B. 1997. "Negotiating Planning Gains through the British Development Control System." Urban Studies 34 (12): 2003-2022. doi: https://doi.org/10.1080/0042098975196

Deeming, H. Whittle, R. and Medd, W. 2011. "Investigating resilience, through 'before and after' perspectives on residual risk." In Innovative thinking in risk, crisis, and disaster management, edited by Bennett, S., 173-200. Surrey: Gower Publishing Limited.

Department for Communities and Local Government. 2015. "Plain English guide to the planning system." Department for Communities and Local Government. Accessed August 20 2017. https://www.gov.uk/government/publications/plain-english-guide-to-theplanning-system

Department for Communities and Local Government. 2017. "Planning Practice Guidance: Local plans." Department for Communities and Local Government. Accessed August 15 2017. https://www.gov.uk/guidance/local-plans--2

Department for Environment, Food and Rural Affairs (DEFRA), Department for Business, Energy and Industrial Strategy (DBEIS), Met Office Hadley Centre and Environment Agency. 2018. "UKCP18 Headline Findings". Met Office. Accessed 7 May 2019. https://www.metoffice.gov.uk/binaries/content/assets/metofficegovuk/pdf/research/ukcp/u kcp18-headline-findings.pdf

Dhar, T.K. and Khirfan, L. 2017. "Climate change adaptation in the urban planning and design research: missing links and research agenda", Journal of Environmental Planning and Management, 60 (4): 602-627. doi: https://doi.org/10.1080/09640568.2016.1178107

Dupuis, J. and Biesbroek, R. 2013. "Comparing apples and oranges: The dependent variable problem in comparing and evaluating climate change adaptation policies." Global Environmental Change, 23: 1476-1487. doi: https://doi.org/10.1016/j.gloenvcha.2013.07.022

Environment Agency. 2015. "No regrets planning for sea level rise and climate change and investing in adaptation." Environment Agency. Accessed August 17 2017. http://primec.net/wp-content/uploads/2015/08/4305_No_Regrets_August2015_final_LR.pdf

Environment Agency. 2016. "Managing flood and coastal erosion risks in England - 1 April 2015 to 31 March 2016." Environment Agency. Accessed August 102017. https://www.gov.uk/government/uploads/system/uploads/attachment_data/file/611614/Nat ional_Flood_Risk_Report_LIT_10517.pdf

Fletcher, S. and Potts, J. 2008. "Coastal and marine governance in the United Kingdom: editorial.” Geographical Journal 174 (4): 295-298. doi: https://doi.org/10.1111/j.14754959.2008.00293.x 
Gehrels, R. \& Long, A. 2008. "Sea level is not level: the case for a new approach to predicting UK sea-level rise." Geography. 93 (1): 11-16.

Greiving, S. and Fleischhauery, M. 2012. "National Climate Change Adaptation Strategies of European States from a Spatial Planning and Development Perspective." European Planning Studies 20: 27-48. doi: https://doi.org/10.1080/09654313.2011.638493

Harlan, S.L. Brazel, A.J. Prashad, L. Stefanov, W.L. and Larsen, L. 2006. "Neighbourhood microclimates and vulnerability to heat stress." Social Science \& Medicine 63 (11): 28472863. doi: https://doi.org/10.1016/j.socscimed.2006.07.030

Hart, T. 2015. "The management of development." In Town and Country Planning in the UK, edited by Cullingworth, B. Nadin, V. Hart, T. Davoudi, S. Pendlebury, J. Vigar, G. Webb, D. and Townshend, T. 137-198. Abingdon: Routledge.

Jennings, T. L. 2011. "Transcending the Adaptation/Mitigation Climate Change Science Policy Debate: Unmasking Assumptions about Adaptation and Resilience." Weather, Climate and Society 3: 238-248. doi: https://doi.org/10.1175/WCAS-D-11-00056.1.

Kuklicke, C. and Demeritt, D. 2016. "Adaptive and risk-based approaches to climate change and the management of uncertainty and institutional risk: The case of future flooding in England". Global Environmental Change 37: 56-68. doi: https://doi.org/10.1016/j.gloenvcha.2016.01.007.

Kron, W. 2013. "Coasts: the high-risk areas of the world." Natural Hazards 66: 1363-1382. doi: https://doi.org/10.1007/s11069-012-0215-4

Luber, G. and McGeehin, M. 2008. "Climate Change and Extreme Heat Events." American Journal of Preventive Medicine 35 (5): 429-435. doi: https://doi.org/10.1016/j.amepre.2008.08.021

Marine Management Organisation (MMO). 2011. "Maximising the socio-economic benefits of marine planning for English coastal communities." London: Roger Tym and Partners and Oxford Consultants for Social Inclusion.

Ministry of Housing, Communities and Local Government (MHCLG). 2012. "National Planning Policy Framework." CP48, Ministry of Housing, Communities and Local Government. Accessed 7 May 2019. https://assets.publishing.service.gov.uk/government/uploads/system/uploads/attachment_d ata/file/779764/NPPF_Feb_2019_web.pdf

Meerow, S. and Mitchell, C. L. 2017. 'Weathering the storm: The politics of urban climate change adaptation planning', Environment and Planning A: Economy and Space 49 (11): pp. 2619-2627. doi: 10.1177/0308518X17735225.

Office for National Statistics. 2014. "2011 Census: Coastal Communities”. Newport: ONS. Accessed 15 January, 2019. https://www.gov.uk/government/statistics/2011-censusanalysis-coastal-communities 
Picketts, I. M. Dery, S. J. and Curry, J. A. 2014. "Incorporating climate change adaptation into local plans." Journal of Environmental Planning and Management 57 (7): 984-1002. doi: https://doi.org/10.1080/09640568.2013.776951

Porter, J. and Demeritt, D. 2012. 'Flood-Risk Management, Mapping, and Planning: The Institutional Politics of Decision Support in England'. Environment and Planning A: Economy and Space 44 (10): pp. 2359-2378. doi: 10.1068/a44660.

Porter, J.J., Demeritt, D. and Dessai, S. 2015. "The right stuff? informing adaptation to climate change in British Local Government". Global Environmental Change 35: 411422. doi: https://doi.org/10.1016/j.gloenvcha.2015.10.004.

Rickey, B. and Houghton, J. 2009. "Solving the riddle of the sands: Regenerating England's seaside towns." Journal of Urban Regeneration and Renewal 3 (1): 46-55.

Romsdahl, R.J., Kirilenko, A., Wood, R.S. and Hultquist, A. 2017. "Assessing National Discourse and Local Governance Framing of Climate Change for Adaptation in the United Kingdom". Environmental Communication. 11 (4): 515-

536. doi: $\underline{10.1080 / 17524032.2016 .1275732}$

Storbjork, S. and Hjerpe, M. 2013. "'Sometimes Climate Adaptation is Politically Correct': A Case Study of Planners and Politicians Negotiating Climate Adaptation in Waterfront Spatial Planning." European Planning Studies 22 (11): 2268-2286. doi: https://doi.org/10.1080/09654313.2013.830697

Sussams, L. W. Sheate, W. R. and Eales, R. P. 2015. "Green infrastructure as a climate change adaptation policy intervention: Muddying the waters or clearing a path to a more secure future?" Journal of Environmental Management 147: 184-193. doi: https://doi.org/10.1016/j.jenvman.2014.09.003

Termeer, C.J.A.M., Dewulf, A. and Robbert Biesbroek, G. 2017. "Transformational change: governance interventions for climate change adaptation from a continuous change perspective", Journal of Environmental Planning and Management, 60 (4): 558-576, doi: https://doi.org/10.1080/09640568.2016.1168288

TCPA (Town and Country Planning Association). 2012. "Planning for climate change guidance for local authorities." Town and Country Planning Association. Accessed July 7 2017. http://www.rtpi.org.uk/media/505555/planning_for_climate_changeguidance_for_local_au thorities rtpi_endorsed_1_2012.pdf

TCPA (Town and Country Planning Association). 2016. "Planning for the climate challenge? Understanding the performance of English local plans." Town and Country Planning Association. Accessed August 12017. https://www.tcpa.org.uk/Handlers/Download.ashx?IDMF=7d92ec4c-09f7-4b21-9d22b1aad77fd062

Townshend, T. 2015. "Design and the Planning System." In Town and Country Planning in the UK, edited by Cullingworth, B. Nadin, V. Hart, T. Davoudi, S. Pendlebury, J. Vigar, G. Webb, D. and Townshend, T. 351-374. Abingdon: Routledge. 
Twigger-Ross, C. Brooks, K. Papadopoulou, L. Orr, P. Sadauskis, R. Coke, A. Simcock, N. Stirling, A. and Walker, G. 2015. "Community resilience to climate change: an evidence review.” Joseph Rowntree Foundation. Accessed: July 252017. https://www.jrf.org.uk/report/community-resilience-climate-change

Uyl, R.M.D. and Russel, D.J. 2018. "Climate adaptation in fragmented governance settings: the consequences of reform in public administration". Environmental Politics. 27 (2): 341361. doi: $\underline{10.1080 / 09644016.2017 .1386341}$

Vardoulakis, S. Dear, K. Hajat, S. Heaviside, C. Eggen, B. and McMichael, A. 2014. "Comparative Assessment of the Effects of Climate Change on Heat- and Cold-Related Mortality in the United Kingdom and Australia." Environmental Health Perspectives 122 (12): 1285-1292. doi: 10.1289/ehp.1307524

Vega-Leinert, A. C. and Nicholls, R. J. 2008. "Potential Implications of Sea-Level Rise for Great Britain." Journal of Coastal Research 24 (2): 342-357. doi: https://doi.org/10.2112/07A-0008.1

Walker, G. and Burningham, K. 2011. "Flood risk, vulnerability and environmental justice: Evidence and evaluation of inequality in a UK context." Critical Social Policy 31 (2): 216240. doi: https://doi.org/10.1177/0261018310396149

Wilson, E. 2006. "Adapting to climate change at the local level: the spatial planning response." Local Environment 11 (6): 609-625. doi: https://doi.org/10.1080/13549830600853635

Zsamboky, M. Fernández-Bilbao, A. Smith, D. Knight, J. and Allan, J. 2011. "Impacts of climate change on disadvantaged UK coastal communities." Joseph Rowntree Foundation. Accessed June 24 2017. https://www.jrf.org.uk/report/impacts-climate-changedisadvantaged-uk-coastal-communities 
Table 1. Breakdown of sections covered in desk-based survey analytical framework, with examples of categories analysed in each

\begin{tabular}{|l|l|}
\hline $\begin{array}{l}\text { Analytical } \\
\text { framework sections }\end{array}$ & $\begin{array}{l}\text { Examples of categories in each section of the framework } \\
\text { against which the local plans were analysed }\end{array}$ \\
\hline $\begin{array}{l}\text { Section one: } \\
\text { Awareness and } \\
\text { understanding }\end{array}$ & $\begin{array}{l}\text { Broad issue of climate change. Need for adaptation to } \\
\text { impacts of climate change. Awareness of: sea-level rise, } \\
\text { hotter summer temperatures, more extreme storms. }\end{array}$ \\
\hline $\begin{array}{l}\text { Section two: } \\
\text { Natural Environment } \\
\text { and Natural Assets }\end{array}$ & $\begin{array}{l}\text { Risks to species and habitats from changing climate space. } \\
\text { Saltwater intrusion risks to aquifers, farmland and habitats. } \\
\text { Threats/opportunities from new species colonisations. }\end{array}$ \\
\hline $\begin{array}{l}\text { Section three: } \\
\text { People and the Built } \\
\text { Environment }\end{array}$ & $\begin{array}{l}\text { Risks to public health and wellbeing from high } \\
\text { temperatures. Risks to people, communities and buildings } \\
\text { from flooding. Risks to culturally valued structures/historic } \\
\text { environment. }\end{array}$ \\
\hline $\begin{array}{l}\text { Section four: } \\
\text { Business and Industry }\end{array}$ & $\begin{array}{l}\text { Risks to business from loss of coastal locations. Employee } \\
\text { productivity impacts in heatwaves and severe weather } \\
\text { infrastructure disruption. Disruption to supply chains. }\end{array}$ \\
\hline $\begin{array}{l}\text { Section five: } \\
\text { Adaptation strategies }\end{array}$ & $\begin{array}{l}\text { Adaptive management of natural habitats, green } \\
\text { infrastructure, sustainable urban drainage systems, climate } \\
\text { change resilient urban design, facilitating coastal retreat. }\end{array}$ \\
\hline
\end{tabular}

Source: Sections and individual categories adapted from the UK Climate Change Risk Assessment report (Committee on Climate Change, 2017b). 
Table 2. Breakdown of the scoring scheme for the desk-based analysis of local plans with an example of how it was used in practice.

Each plan was assessed for the level of attention it addressed each projected climate change risk. Alongside qualitative comments, a score of between 0 and 4 points was assigned based upon how much prominence the risk was given in the local plan.

\begin{tabular}{|c|c|c|}
\hline Score & Definition of score & $\begin{array}{l}\text { Example of scoring in practice } \\
\text { (e.g. Risk to public health and wellbeing from } \\
\text { high temperatures.) }\end{array}$ \\
\hline $\begin{array}{l}4 \\
\text { points }\end{array}$ & $\begin{array}{l}\text { Climate change } \\
\text { risk is identified } \\
\text { and addressed } \\
\text { directly in the bold } \\
\text { wording of a local } \\
\text { plan policy. }\end{array}$ & $\begin{array}{l}\text { A local plan policy specifically mentions the } \\
\text { increasing risk to public health and wellbeing from } \\
\text { rising average summer temperatures as a result of } \\
\text { climate change and includes measures to address this } \\
\text { risk. }\end{array}$ \\
\hline $\begin{array}{l}3 \\
\text { points }\end{array}$ & $\begin{array}{l}\text { Climate change } \\
\text { risk is indirectly } \\
\text { addressed in the } \\
\text { bold wording of a } \\
\text { local plan policy. }\end{array}$ & $\begin{array}{l}\text { Local plan features a policy acknowledging the } \\
\text { Urban Heat Island (UHI) effect and its impacts upon } \\
\text { health and wellbeing and puts forward measures to } \\
\text { address this. However, it does not } \\
\text { acknowledge/address the additional impacts of rising } \\
\text { average summer temperatures due to climate change } \\
\text { upon UHI intensity. }\end{array}$ \\
\hline $\begin{array}{l}2 \\
\text { points }\end{array}$ & $\begin{array}{l}\text { Climate change } \\
\text { risk is addressed } \\
\text { directly in the } \\
\text { contextual or } \\
\text { justification text in } \\
\text { the local plan only. }\end{array}$ & $\begin{array}{l}\text { Acknowledgment of risks to public health and } \\
\text { wellbeing from higher average summer temperatures } \\
\text { in the future as a challenge for the future, but this is } \\
\text { not addressed with a policy response. }\end{array}$ \\
\hline 1 point & $\begin{array}{l}\text { Climate change } \\
\text { risk is indirectly } \\
\text { addressed in the } \\
\text { contextual/justificat } \\
\text { ion text in the local } \\
\text { plan only. }\end{array}$ & $\begin{array}{l}\text { Acknowledgement of increasing average summer } \\
\text { temperatures or heatwave occurrences with } \\
\text { implications for the local area, but no explicit link } \\
\text { made to the particular implications for human health } \\
\text { and wellbeing. }\end{array}$ \\
\hline $\begin{array}{l}\text { 0 } \\
\text { points }\end{array}$ & $\begin{array}{l}\text { Climate change } \\
\text { risk is not } \\
\text { addressed } \\
\text { anywhere in the } \\
\text { local plan. }\end{array}$ & $\begin{array}{l}\text { Risks to public health and wellbeing from high } \\
\text { temperatures in the local plan document are not } \\
\text { acknowledged/addressed directly or indirectly by the } \\
\text { local plan. }\end{array}$ \\
\hline
\end{tabular}

Source: Scoring scheme devised by the author, based upon methodology by Baker et al., (2012) and research by the TCPA (2016). 
Table 3. Numbers of local authority plans that explicitly acknowledge various climate risks relating to people and the built environment or business and industry

\begin{tabular}{|l|c|c|}
\hline $\begin{array}{l}\text { Risks from climate change identified for } \\
\text { the UK }\end{array}$ & $\begin{array}{l}\text { Number of } \\
\text { local authority } \\
\text { plans that } \\
\text { explicitly } \\
\text { recognise }\end{array}$ & $\begin{array}{l}\text { Number of local } \\
\text { authority plans } \\
\text { that address } \\
\text { explicitly } \\
\text { through policy }\end{array}$ \\
\hline $\begin{array}{l}\text { Risks to public health and wellbeing from } \\
\text { high temperatures. }\end{array}$ & 6 & 0 \\
\hline $\begin{array}{l}\text { Risks to people, buildings, businesses or } \\
\text { infrastructure from flooding. }\end{array}$ & 39 & 38 \\
\hline Risks to health and social care delivery. & 2 & 1 \\
\hline $\begin{array}{l}\text { Risks to culturally valued structures and } \\
\text { historic environment. }\end{array}$ & 8 & 15 \\
\hline $\begin{array}{l}\text { Risks of household or business water supply } \\
\text { interruptions. }\end{array}$ & 27 & 12 \\
\hline $\begin{array}{l}\text { Risks to businesses from loss of coastal } \\
\text { locations and infrastructure. }\end{array}$ & 15 & \\
\hline
\end{tabular}

Source: Author's original research (desk based local plan analysis). 

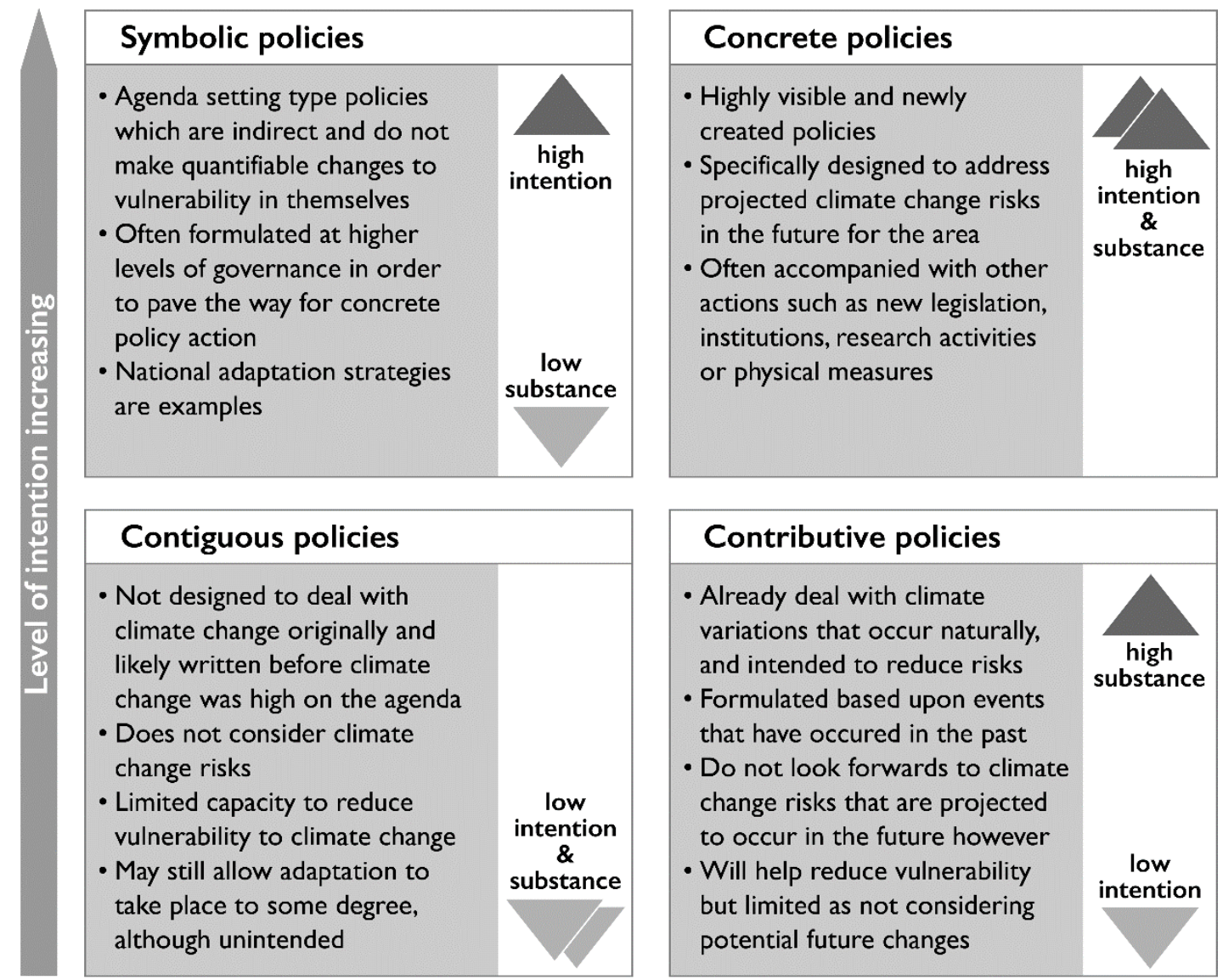

\section{Contributive policies}

- Already deal with climate variations that occur naturally, and intended to reduce risks

- Formulated based upon events that have occured in the past

- Do not look forwards to climate change risks that are projected to occur in the future however

- Will help reduce vulnerability but limited as not considering potential future changes

Figure 1. Classification of climate change adaptation policies in spatial planning strategies. Source: Adapted from Dupuis and Biesbroek (2013). 


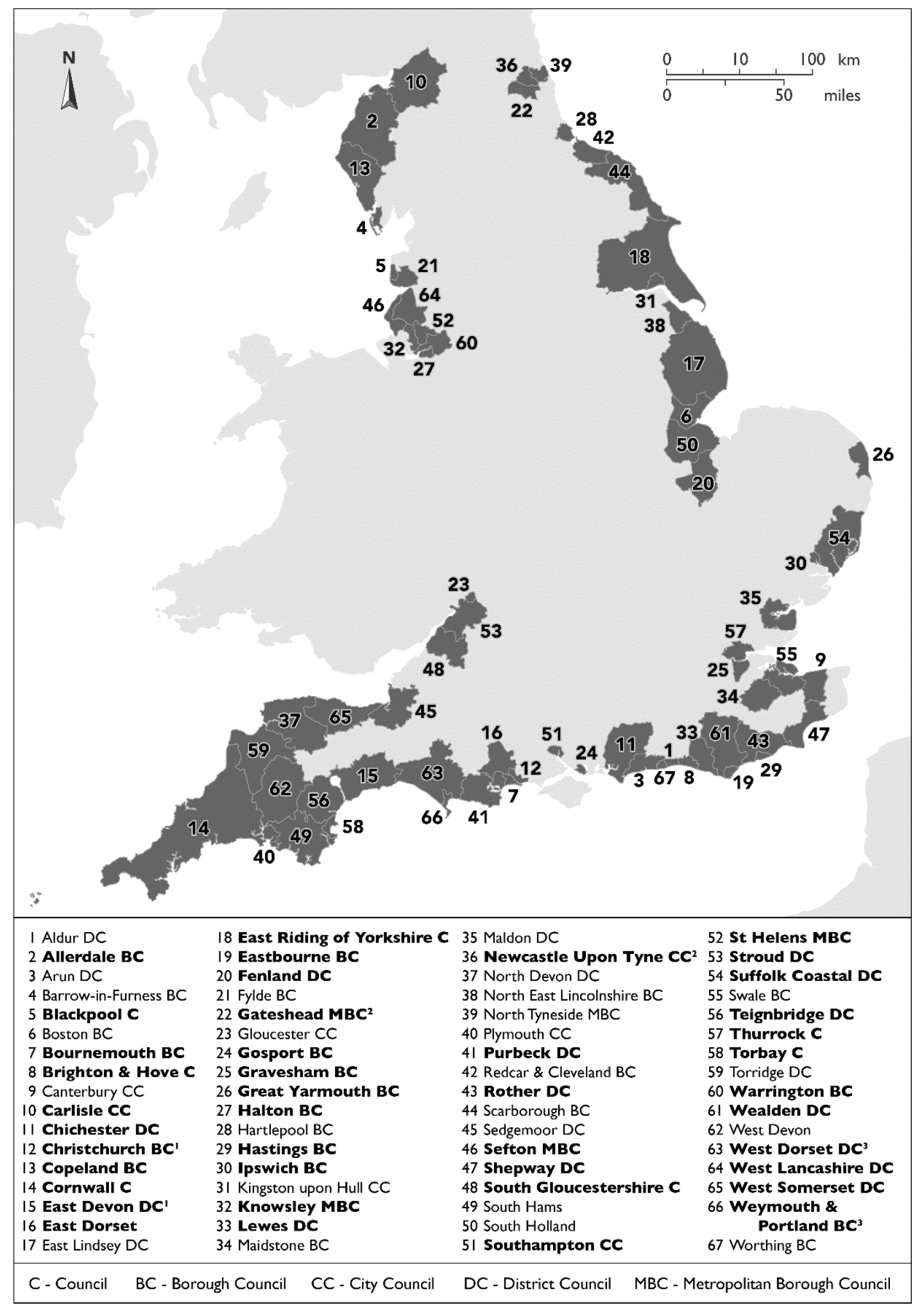

Figure 2. Coastal local authorities with Local Plans in preparation or adopted in the last five years (September 2012 - 2017) (shaded), with those fully adopted and included in the desk based analysis indicated by bold text in the list. Footnotes denote those authorities with a Joint Local Plan (three in total: 1 Christchurch Borough Council/ East Dorset; 2 Gateshead Metropolitan Borough Council/Newcastle upon Tyne City Council; 3 West Dorset District Council/ Weymouth and Portland Borough Council). 